\title{
Phenomenography: A Missed Method in Medical Research
}

\author{
Abdolghader Assarroudi ${ }^{1}$, Abbas Heydari² \\ ${ }^{1}$ PhD candidate in Nursing, School of Nursing and Midwifery, Mashhad University of Medical Sciences, \\ Mashhad, Iran \\ ${ }^{2}$ Evidence-Based Research Centre, Department of Medical-Surgical Nursing, School of Nursing and \\ Midwifery, Mashhad University of Medical Sciences, Mashhad, Iran
}

\begin{abstract}
SUMMARY
Research is an approach with which human beings can attempt to answer questions and discover the unknowns. Research methodology is something that is determined by the researcher's attitude toward the universe as well as by the question he is trying to answer. Some essential questions regarding the research process are: "What is the nature of reality?", "What is the nature of the relationship between the scholar and the subject of interest?", and "How can one understand the subject, and what are the methods?". Research approaches can be categorized as quantitative and qualitative. In the former, measurement, prediction, and control are the bases, while in the latter, exploring, describing, and explaining the phenomena are fundamental. Among qualitative research methods, phenomenography is one of the newest methods. However, in spite of proving to be useful in various disciplines, it has yet to become popular, and many scholars mistake it for phenomenology. The focus of phenomenography is on what is known as the second-order perspective and the different ways that people can experience the same phenomenon, while phenomenology primarily emphasizes the first-order perspective and the similar essences that are derived from various experiences. This article aims to provide a better understanding of phenomenography through explaining it and comparing it with phenomenology in order to facilitate its proper and timely application in medical studies.
\end{abstract}

Key words: phenomenography, phenomenology, qualitative method

Corresponding author:

Abbas Heydari

Email: HeidaryA@mums.ac.ir 


\section{INTRODUCTION}

Research and its diverse methodologies have a long history in human-related sciences and have contributed to the understanding of behaviors and ideas of human beings in complex and ever-changing situations (1). Many studies are done using experimental or quantitative methods, and they focus on observable aspects in order to measure, predict, and control the phenomenon of interest. But, many human behaviors are not measurable and predictable by the use of this approach. On the other hand, there are qualitative methods which emphasize exploring, describing, and explaining human behavior $(2,3)$, and these can be employed to study human behaviors with an approach that goes beyond quantification. These methods help scholars to understand thoughts, emotions, and behaviors of people in various situations and contexts $(4,5)$. One less known qualitative method is phenomenography which was first introduced by Ference Marton and his colleagues in $1970(1,6)$. This research method originated from studies that were done on educational psychology in Sweden's Gutenberg University. At that institute, the scholars were interested in qualitative evaluating of learning and thinking experiences (6) which eventually led to the development of the phenomenographic method (7).

The term phenomenography consists of two Greek words: phainomenon which means becoming visible and luminous, and graphia which means describing something (8). This term was first introduced by Sonnemann in 1954, but the real momentum to develop phenomenography as a research approach did not begin until the 1970s. Before the 70s, phenomenography was mostly used for understanding the domain and boundaries of a phenomenon, but Marton further developed it to describe, analyze, and understand various individual experiences (6). The main purpose of phenomenography is to describe phenomena (7). It presents a set of assumptions regarding human beings and science, and it explores the various qualitative means by which individuals experience their world $(1,6)$. At this point, however, phenomenography is still at the beginning of its application in some fields, such as trade, nursing, and information technology $(1,9$, 10). The basic assumptions of phenomenography are as follows: different people do not experience a phenomenon in a same way, and instead, people have a wide variety of perceptions and understandings about phenomena (11); a single person may not be able to explain all aspects of a concept (experience) $(12,13)$, and a person may have more than one concept (experience) related to a specific phenomenon in his mind $(12,13)$.

Many studies using phenomenography focus on describing different qualitative methods of experiencing a single phenomenon $(1,6,14,15)$. This emphasis on various ways of experiencing and understanding a phenomenon is the main distinction between phenomenography and other qualitative research methods $(1,6)$. This method organizes the basic assumptions regarding human beings and science, and it develops knowledge about the different ways of experiencing the universe by different people.

\section{Differences between phenomenography and phenomenology}

Phenomenography, much like phenomenology, tries to evaluate human experience and knowledge. The main difference is in their purposes. The main purpose of phenomenography is to describe the variety of experiences regarding phenomenon in the universe (1), while the main purpose in phenomenology is to reach the essence or meaning of the phenomenon $(6,16)$. Another difference of phenomenography, as opposed to phenomenology, is its distinction between firstorder and second-order perspectives. Marton referred to the first-order perspective as the question of "what a thing really is" and the secondorder perspective as the question of "how a thing is perceived" $(1,7)$ (Figure 1).

The famous story of the elephant in a dark room and people's different perceptions of it when they touched its different parts is an almost perfect example for describing phenomenography. By collecting and integrating different experiences of a single entity (the elephant), we can have a better and more precise understanding of the entity as a whole (18). In other words, phenomenography can be described as a jigsaw puzzle and different people's experiences as its different parts; thus, these parts together can present a complete image of the phenomenon (19).

The differences between phenomenography and phenomenology are summarized in Table 1. 


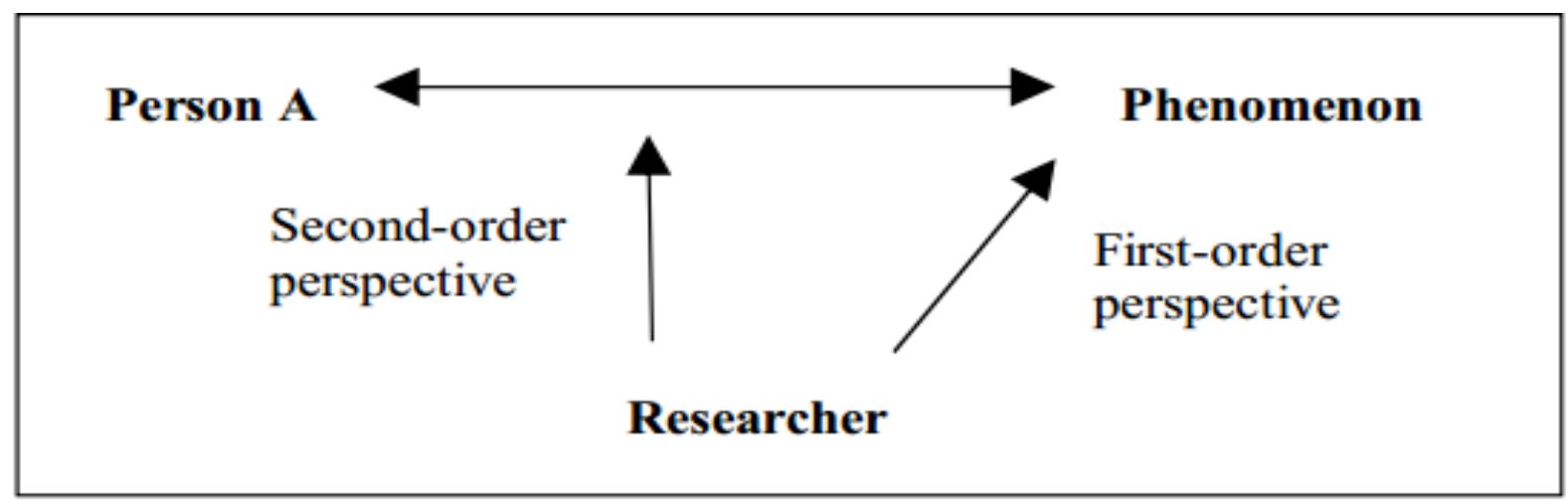

Figure 1: Comparing the first and second-order perspectives; from Uljens. 1991 (17)

Table 1: Comparing phenomenography and phenomenology

\begin{tabular}{c|c}
\hline \hline Phenomenography & Phenomenology \\
\hline $\begin{array}{c}\text { The aim is to describe the variety of perceptions } \\
\text { and understandings of the experienced } \\
\text { phenomenon from different viewpoints. }\end{array}$ & $\begin{array}{c}\text { The aim is to reveal the essence of a } \\
\text { phenomenon of interest. }\end{array}$ \\
\hline $\begin{array}{c}\text { Second-order perspective is the main approach } \\
\text { which tries to describe the perception of a } \\
\text { participant regarding an experience. }\end{array}$ & $\begin{array}{c}\text { First-order perspective is the main approach } \\
\text { which tries to describe the essence of the } \\
\text { phenomenon, requiring phenomenological } \\
\text { reduction of the experience. }\end{array}$ \\
\hline $\begin{array}{c}\text { Analysis would lead to recognizing perceptions } \\
\text { and outcome space. }\end{array}$ & $\begin{array}{c}\text { Analysis would lead to recognizing meaning } \\
\text { units (6). }\end{array}$ \\
\hline \hline
\end{tabular}

\section{Describing phenomenography}

Marton defines consciousness as the relationship between the object and subject and indicates that, when something piques one's interest, he would think about it and try to understand it. Therefore, in this school of thought, not only are the object and subject not separated, they are also connected to each other and form a single entity. Consciousness is defined as the person's general experience of the universe at a given point in time $(20,21)$. Phenomenography is within the interpretivist paradigm, which has a subjective position regarding ontology but maintains an objective position regarding epistemology. Therefore, it attempts to understand how people interpret and give meaning to their surrounding phenomena, as well as understanding how they make their world based on their interpretation of the phenomena (19).

Phenomenographers evaluate the structure and components of people's experiences (concepts, ways of seeing, perception, and understanding) and finally provide a holistic picture of the different ways of experiencing the phenomenon. According to Marton and Wing, each concept (experience) has two interconnecting components: referential and structural (22). The referential component is the general and universal meaning of the concept, while the structural component consists of external and internal horizons. An external horizon demonstrates the part of the universe beyond which a participant with a specific viewpoint toward the universe cannot see. In other words, it separates an experience from its context and links it with other contexts. An internal horizon 
indicates the focus of the participant's attention and has a stable aspect along with one or more variable aspects. In other words, an internal horizon is a way to decompose the elements of a specific experience and to determine their relationships with each other as well with the whole entity. The pivotal element in determining the specific perception method in each experience is the stable aspect of internal horizon (23) (Figure 2).

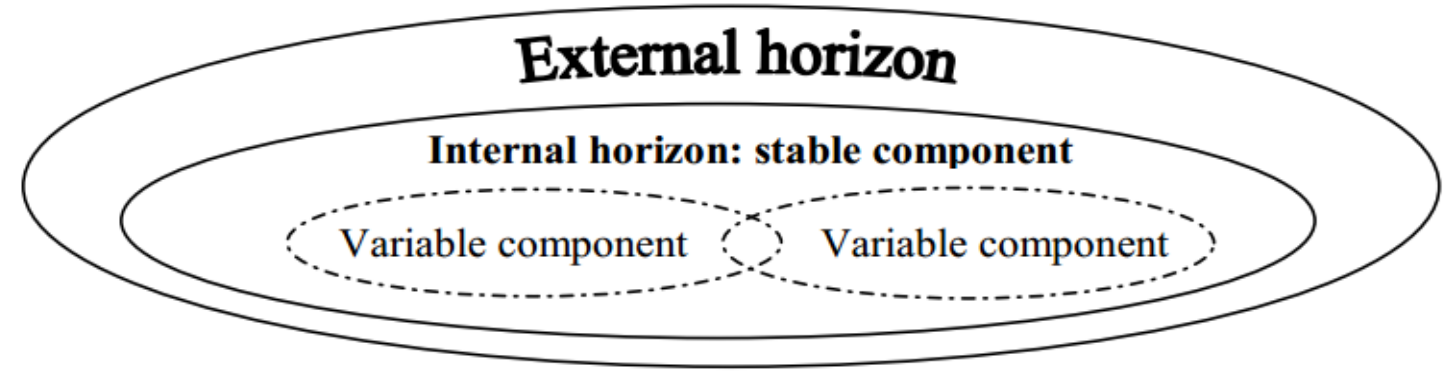

Figure 2: Key components of each concept (experience); from Bruce et al. 2002 (24)

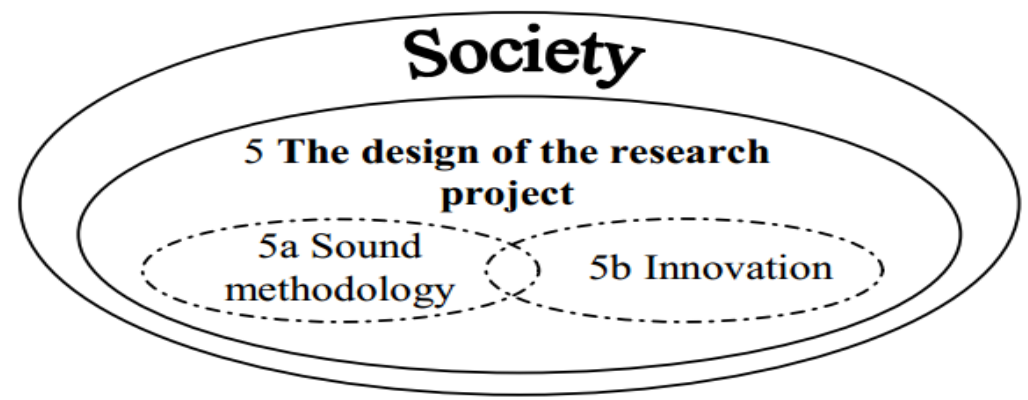

Figure 3. Concept (experience) components for understanding research project; from Bruce et al., 2002 (24)

For example, in a study by Bruce et al. conducted to understand the standards of an "important and valuable study" according to various researchers, one of the resulting categories was "the design of the research project," which is a stable aspect of the internal horizon and consists of "sound methodology" and "innovation," all of which are included in an external horizon named "society" (Figure 3).

The data collecting method in phenomenography is usually a semi-structured interview. It is recommended that several initial questions be included in the research guide to help in developing the conversation. In each interview, a comprehensive dialogue regarding the main subject is of great importance in order to achieve a clear understanding. The interviewer should be assured of the openness of the interview and the sufficiency of time for thinking and pausing during the interview (8, 25).

\section{Steps of phenomenography}

Different classifications of steps have been proposed for phenomenography research. One of these, which is the most comprehensive and wellknown classification, has been introduced by Järvinen. It includes the following steps: defining the subject as well as restricting it, selecting participants and interviewing them, putting the interviews on paper, analyzing the interviews, and putting the analysis results in categories of description $(8,26)$.

In the first step, the phenomenon and its analysis level should be precisely determined. Examining different dimensions of the subject through reviewing the literature will lead to more precise cognition and help to restrict the subject. Moreover, a literature review assures a better design of the main and probing questions, as well as a proper understanding about other researchers' conceptions (26). 
During phenomenographic interviews, which are performed semi-structurally $(1,27)$, participants who have experienced the phenomenon and are willing to share their ideas about it are interviewed. Participants are selected purposefully, usually using the snowball method (28). Maximum variation sampling is used with the aim of attaining diverse experiences regarding the same phenomenon (29). As with other qualitative methods, interviewing participants will continue to achieve data saturation (19). Raw data are analyzed using the constant comparative method, and after initial coding, the comparison of the codes' similarities and differences will result in the emergence of specific categories of description. A constant review of the interview texts is necessary to ensure that categories are properly descriptive and compatible with the data (30). Dahlgren and Fallsberg define seven steps for analyzing the interview data in phenomenography studies: "familiarization; compilation; condensation; preliminary grouping or classification of similar answers; preliminary comparison of categories; naming the categories to emphasize their essence; and contrastive comparison of categories" $(1,31)$.

The categories of description demonstrate different concepts of a single phenomenon held by a person, or a group of people, and should be determined in a model including a referential component, structural component, external horizon, and internal horizon with its specific aspects. Integrating all categories would lead to a more holistic and multi-dimensional picture of the phenomenon of interest, which is called "outcome space" (24). The outcome space leads to a deeper understanding of participant's different "ways of seeing" and the interrelation between them (20). Also, internal compatibility and conciseness should be noted in the formation of categories (19).

\section{Application in medical sciences}

The essential achievement of phenomenography is precise cognition, which has a pivotal role in delivering individualized services in health and education areas (6).

Understanding the differences in patients' experiences regarding their diseases, injuries, treatments, interventions, and their needs helps us in providing such individualized services. For instance, the phenomenon of pregnancy may yield different experiences and perceptions to different women. Some may perceive it positively, while others may perceive it negatively. This produces distinct needs, so that different care plans will be required.

Moreover, in medical education, considering the differences in teaching and learning phenomena, as perceived by teachers and learners, will facilitate the interaction of different learners and encourage the use of different strategies according to their unique experiences. These examples show that the phenomenographic approach offers a proper worldview for considering the diverse experiences of individuals in order to provide them with appropriate intervention.

\section{DISCUSSION}

Despite extensive usage of qualitative methods in health care studies, phenomenography has not been adequately promoted or considered, despite the fact that delivering appropriate care to patients according to their differences has been emphasized by the profession as a high priority goal (32, 33). Therefore, phenomenography, because of its inherent properties, may be a means to reach that goal.

Some scholars criticize phenomenography as they regard it to be the same as phenomenology, thus challenging its originality (34). Marton, as a pioneer in phenomenography, accepts the similarities of these methods, such as having a communicative nature, emphasizing lived experiences, and adopting qualitative approaches (7). However, their differences show a fundamental distinction between the methods (Table 1). The authors believe that phenomenology, as compared to phenomenography, attempts to get a deeper insight regarding the particular phenomenon of interest, while phenomenography helps the researcher in acquiring a more comprehensive perception of the phenomenon by providing the outcome space. Another criticism is that, in phenomenography, only one category among various categories of description is selected, while other categories are considered incorrect (35). This criticism is rooted in a misunderstanding of the philosophical and theo- 
retical bases of phenomenography because this method does not consider one category as predominant, and if it did, that would be the fault of the researcher and not the method.

A third criticism mounted against both phenomenography and phenomenology (35) is the attempt of the researcher to bracket his or her preconceptions about the phenomenon during data gathering and analysis (36). Most qualitative researchers are in favor of bracketing, though they are not certain about its possibility $(35,37)$.

Another criticism propounded by Sjöström and Dahlgren is in regard to the phenomenographic interview, and it concerns the motivation of the respondent to participate in the study, as well as the researcher's understanding of what the respondent tries to convey (1). Obviously, these problems are involved in all qualitative studies in which the interview is used for data gathering, and they are not exclusively associated to phenomenography. These concerns could be obviated through selecting participants for whom the phenomenon of the study is also important and by immediately interpreting the interview content and constructing probing questions (1).

\section{CONCLUSION}

Despite the fact that more than four decades have passed since the introduction of the phenomenographic method by Marton, it has received little attention in medical studies, whereas the goal of delivering treatment, care, and education that respects and responds to individual differences has become central to modern medicine and medical education values. In this study, our aim was to explain the steps of the phenomenographic method, while analyzing interview data and the ontological and epistemological bases of the method at the same time. This may help to better understanding the method and could enhance the possibility of its use in future studies.

\section{Acknowledgements}

We wish to thank Dr. Mohammad Reza Armat who provided insight and expertise that greatly assisted the manuscript. 


\section{References}

1. Sjöström B, Dahlgren LO. Applying phenomenography in nursing research. J Adv Nurs. 2002;40(3):339-45. http://dx.doi.org/10.1046/j.1365-2648.2002.02375.x

2. Speziale HS, Streubert HJ, Carpenter DR. Qualitative research in nursing: Advancing the humanistic imperative. 5th ed. China: Lippincott Williams \& Wilkins; 2011.

3. Flick U. Mapping the Field. In: Flick U, editor. The Sage handbook of qualitative data analysis. Los Angeles: Sage; 2013. P. 3-18.

4. Polit DF, Beck CT. Essentials of nursing research: Appraising evidence for nursing practice. 7th ed. China: Wolters Kluwer Health | Lippincott Williams \& Wilkins.; 2010.

5. Taylor MC. Interviewing. In: Holloway I, editor. Qualitative research in health care. Berkshire: McGraw-Hill International; 2005. p. 39-55.

6. Barnard A, McCosker H, Gerber R. Phenomenography: a qualitative research approach for exploring understanding in health care. Qual Health Res. 1999;9:212-26.

http://dx.doi.org/10.1177/104973299129121794

7. Marton F. Phenomenography-describing conceptions of the world around us. Instr Sci. 1981;10:177200.

http://dx.doi.org/10.1007/BF00132516

8. Kaapu T, Saarenpää T, Tiainen T, Paakki M-K. The Truth is Out There-Phenomenography in Information Systems Research. Proceedings of the 29th Information Systems Research Seminar in Scandinavia; 2006; Helsingör, Denmark. 2006.

9. Maybee C. Undergraduate perceptions of information use: the basis for creating usercentered student information literacy instruction. The Journal of Academic Librarianship. 2006;32(1):79-85.

http://dx.doi.org/10.1016/j.acalib.2005.10.010

10. Pimpa N, Boucher C, Fisher G, editors. The nature of the online education engagement in the international business program: A phenomenographic study. the ANZIBA Conference 2009; Australia and New Zealand International Business Academy. 2009.

11. Marton F. Postlethwaite TN, Husen T. Phenomenography. The International Encyclopedia of Education Oxford: Pergamon Press.1994: 44244429.

12. Henderson CR. Faculty conceptions about the teaching and learning of problem solving in introductory calculus-based physics. Doctoral dissertation, University of Minnesota. 2002.

13. Boon S, Johnston B, Webber S. A phenomenographic study of English faculty's conceptions of information literacy. Journal of documentation. 2007;63:204-28.

http://dx.doi.org/10.1108/00220410710737187

14. Linder C, Marshall D. Reflection and phenomenography: towards theoretical and educational development possibilities. Learn Instr. 2003;13:271-84.

http://dx.doi.org/10.1016/S0959-4752(02)00002-6

15. Ramritu P, Barnard A. New nurse graduates' understanding of competence. Int Nurs Rev. 2001;48(1):47-57.

http://dx.doi.org/10.1046/j.1466-7657.2001.00048.x

16. Laverty SM. Hermeneutic Phenomenology and Phenomenology: A Comparison of Historical and Methodological Considerations. Int J Qual Methods. 2003;2:1-29.

17. Uljens M. Phenomenography-a qualitative approach in educational research. Kasvatustutkimuksen laadullisia lähestymistapoja Kvalitatiivisten tutkimusmenetelmien seminaari Oulussa. 1991;11(13.10):1990 .

18. McAuley J, Duberley J, Johnson P. Organization theory: Challenges and perspectives. Harlow: Prentice Hall; 2007. 
19. Danaee Fard H, Kazemi SH. Promoting Interpretive Research In Organization: Overview Of Philosophical Foundations And Conduction Process Of Phenomenography. Journal Of Management Studies In Development \& Evaluation. 2010;20:12147.

20. Ballantyne R, Bruce C. Proceedings of Phenomenography: philosophy and practice. Centre for Applied Environmental and Social Education Research, Faculty of Education, Queensland University of Technology, Brisbane, 79 November 1994.

21. Flodén A, Forsberg A. A phenomenographic study of ICU-nurses' perceptions of and attitudes to organ donation and care of potential donors. Intensive Crit Care Nurs. 2009;25:306-13. http://dx.doi.org/10.1016/j.iccn.2009.06.002

22. Marton F, Pong WY. On the unit of description in phenomenography. Higher education research \& development. 2005;24(4):335-48.

http://dx.doi.org/10.1080/07294360500284706

23. Svensson L. Theoretical foundations of phenomenography. Higher Education Research \& Development. 1997;16(2):159-71. http://dx.doi.org/10.1080/0729436970160204

24. Bruce CS, Pham BL, Stoodley ID. The Collective Consciousness of Information Technology Research: Ways of seeing Information Technology Research: Its Objects and Territories. Final Report; 2002. retrieved from http://eprints.qut.edu.au/1757

25. Brammer J. A phenomenographic study of registered nurses' understanding of their role in student learning-An Australian perspective. Int J Nurs Stud. 2006;43:963-73.

http://dx.doi.org/10.1016/j.ijnurstu.2005.11.004

26. Järvinen $P$. The new classification of research approaches. The IFIP Pink Summary-36 years of IFIP, Edited by H Zemanek, Laxenburg, IFIP. 1997. Retrieved from http://www.ifip.org/36years/a51jarvi.html

27. Marton F, Booth SA. Learning and awareness. New York: Taylor \& Francis Group; 1997.
28. Angles JM. The impact of shared leadership on the effectiveness of self-managed work teams: A phenomenological study. Doctoral dissertation: University of Phoenix; 2007. retrieved from http://gateway.proquest.com/openurl?url_ver=Z39. 882004\&res_dat=xri:pqdiss\&rft_val_fmt=info:ofi/f mt:kev:mtx:dissertation\&rft_dat=xri:pqdiss:327719 8

29. Flick U. Qualitative research-state of the art. Soc. Sci. Inf. 2002;41(1):5-24. http://dx.doi.org/10.1177/0539018402041001001

30. Orgill M. Phenomenography. Encyclopedia of the Sciences of Learning. US: Springer; 2012: 2608-11. http://dx.doi.org/10.1007/978-1-4419-1428-6_271

31. Dahlgren L-O, Fallsberg M. Phenomenography as a qualitative approach in social pharmacy research. J Soc Adm Pharm. 1991;8(4):150-6.

32. Reynolds A. Patient-centered care. Radiol Technol. 2009;81:133-47 .

33. Bell L. Patient-Centered Care. Am J Crit Care.2014;23:325.

http://dx.doi.org/10.4037/ajcc2014383

34. Richardson JT. The concepts and methods of phenomenographic research. Rev Educ Res. 1999;69(1):53-82.

http://dx.doi.org/10.3102/00346543069001053

35. Webb G. Deconstructing deep and surface: Towards a critique of phenomenography. Higher Education. 1997;33(2):195-212.

http://dx.doi.org/10.1023/A:1002905027633

36. Marton F. The idea of phenomenography. Conference Proceedings. In: Ballantyne R, Bruce C, editors. Phenomenography: philosophy and practice. Brisbane: QUT Publications and Printing; 1994.

37. Dowling M. From Husserl to van Manen. A review of different phenomenological approaches. Int J Nurs Stud. 2007;44(1):131-42.

http://dx.doi.org/10.1016/j.ijnurstu.2005.11.026 


\title{
Fenomenografija: metoda koja je izostavljena u medicinskim istraživanjima
}

\author{
Abdolghader Assarroudi ${ }^{1}$, Abbas Heydari² \\ ${ }^{1}$ Student doktorskih studija iz oblasti bolničke nege, Fakultet za sestrinstvo i akušerstvo, \\ Univerzitet medicinskih nauka Mashhad, Mashhad, Iran \\ ${ }^{2}$ Centar za istraživanja nege zasnovane na dokazima, Odeljenje za medicinsko-hirurško \\ sestrinstvo, Fakultet za sestrinstvo i akušerstvo, \\ Univerzitet medicinskih nauka Mashhad, Mashhad, Iran
}

\begin{abstract}
SAŽETAK
Istraživanje predstavlja pokušaj ljudi da odgovore na određena pitanja i otkriju ono što im je nepoznato. Metodologija istraživanja je određena stavom istraživača prema univerzumu kao i pitanjem na koje želi da da odgovor. Neka od suštinskih pitanja koja se tiču istraživačkog procesa su: "Koja je priroda realnosti?", Kakva je priroda odnosa između istraživača i predmeta interesovanja?" i "Kako se može razumeti predmet istraživanja i koje metode bi trebalo primeniti?" Istraživački pristupi se mogu podeliti na kvantitativne i kvalitativne. U prvom slučaju, merenje, predikcija i kontrola čine osnovu ovog pristupa, dok je u drugom slučaju ispitivanje, opisivanje $i$ objašnjenje fenomena od suštinskog značaja. Među kvalitativnim istraživačkim metodama, fenomenografija se pojavljuje kao novija metoda. Međutim, uprkos tome što se pokazala kao vrlo korisna u različitim disciplinama, još uvek nije dobila na popularnosti i mnogi istraživači je mešaju sa fenomenologijom. Fokus fenomenografije je na onome što se posmatra kao druga perspektiva i na drugačijem doživljaju ljudi istog fenomena, dok fenomenologija prvenstveno naglašava osnovno, neposredno iskustvo i slične sadržaje koji proističu iz različitih iskustava. Cilj ovog rada bio je da pruži bolje razumevanje fenomenografije kroz objašnjenja i poređenja sa fenomenologijom kako bi se olakšala njena adekvatna $i$ pravovremena primena u medicinskim istraživanjima.
\end{abstract}

Ključne reči: fenomenografija, fenomenologija, kvalitativna metoda 